\title{
Profiling the Environmental Sustainability-Conscious (ESC) Consumer: Proposing the S-P-P Model
}

\author{
Steve Ukenna ${ }^{1}$, Anayo D. Nkamnebe ${ }^{2}$, Ireneus C. Nwaizugbo ${ }^{2}$, Shed Chinwuba Moguluwa ${ }^{3} \&$ Moses C. Olise $^{2}$ \\ ${ }^{1}$ Marketing Unit, Department of Business Management, Godfrey Okoye University, Enugu State, Nigeria \\ ${ }^{2}$ Department of Marketing, Nnamdi Azikiwe University, Awka, Nigeria \\ ${ }^{3}$ Department of Marketing, University of Nigeria, Enugu Campus, Enugu, Nigeria \\ Correspondence: Steve Ukenna, Marketing Unit, Department of Business Management, Godfrey Okoye \\ University, Ugwuomu-Nike, P.M.B 01014, Enugu State, Nigeria. Tel: 234-806-920-5016. E-mail: \\ stephenukenna@yahoo.com
}

Received: December 31, 2011 Accepted: March 12, 2012 Online Published: July 5, 2012

doi:10.5539/jms.v2n2p197 URL: http://dx.doi.org/10.5539/jms.v2n2p197

\begin{abstract}
This paper sought to explore the nature of the various measures used for profiling the environmental sustainability conscious (ESC) consumer segment; and to posit a measure that will be most appropriate for profiling this segment.

Design/methodology/approach: Using the $5 \mathrm{~S}$ model for assessing market segmentation approaches, the study critiqued the common measures, which are singly adopted for profiling the ESC segment.

Findings: Contradictory views exist among scholars as to which approach is best for profiling the ESC consumer; the results on the common correlates used by scholars under each approach are also contradictory. Few consistent results exist for each correlate under each approach. Accordingly, to mitigate this shortcoming, this paper posits the S-P-P Model, which is an integrated for profiling the ESC consumer segment.
\end{abstract}

Research limitations/implication: This review is not exhaustive in that it did not review methodological issues that underpin profiling approaches.

Originality/value: The S-P-P model, which this paper posits, offers a comprehensive and robust approach for an individual intending to profile the ESC segment.

Keywords: S-P-P model, Environmental Sustainability-Conscious (ESC) consumer, profiling approaches/measures

\section{Introduction}

Marketing has evolved from transactional paradigm to relational paradigm and, today, the sustainability marketing paradigm has emerged. Thus the present era of sustainable development has stimulated heightening awareness towards the need to be sustainable among policy makers, producers, and consumers. Though at differing degree of sustainability-driven behaviour, the environmental sustainability-conscious (ESC) or green consumer has emerged across the world. According to D'Souza, Taghian, and Lamb (2006) they are consumers who make every effort to search for products that favour the environment. Scypa (2006) in Banyte, Brazioniene and Gadeleikiene (2010) defined green and ESC consumer as consumer who constantly buys eco-friendly products and is actively concerned with environmental issues and solutions to them.

Agreeably, the green market segment is increasing. Consequently, for companies to tap into this segment, country/context-specific or, better still, a more localized research that will unearth the profile of this segment has been called for (Hartono, 2008; Jain and Kaur, 2006). The question that has logically followed this "wake-up call" among academics is: what measure should be used to profile this emerging market segment? Since the 1970s to date, several studies abound in the sustainability marketing literature on profiling this important market segment (e.g., Schlegelmilch, Bohlen and Diamantopoulos, 1996; Straughan and Roberts, 1999; Laroche, Bergeron, and Barbaro-Forleo, 2001; Diamantopoulos, Schlegelmilch, and Sinkovics, 2003; Jain and Kaur, 2006; Hartono, 2008) and different measures were adopted; hence leading to contradictory results. 
The contradictions that persist in literature regarding the approach to adopt in profiling the ESC segment bring us to the tripod objective of this review: (1) to explore the nature of the various measures used for profiling the ESC consumer; (2) to find out which measure or approach is considered most effective in profiling the sustainability-driven consumer; and (3) to determine the measure that will be most appropriate in profiling the ESC consumer segment in the growing ESC segment in Africa. Thus, this review is guided by the following question: what measure/approach is most appropriate for profiling this emerging market segment?

The rest of the paper is structured in a way to enhance the reader's understanding. We begin with a review framework that will guide the reader on how our review is structured. We then proceed to explore the various approaches employed in the literature for profiling the ESC consumer segment. Our review is concluded; we then put forward a number of recommendations. The weaknesses of our review are captured in the limitation section.

\section{Review Framework}

Figure 1 encapsulates the scope of our review. Basically this review is twofold. On one hand, we review the various literature on environmental sustainability construct, wherein we examined the three common domains (knowledge, attitude, and behaviour) of the ESC construct. On the other hand, we review various studies that adopted the existing approaches for profiling the ESC consumer. Common correlates used by researchers under each approach were also reviewed. To determine which approach is most suitable, the $5 \mathrm{~S}$ criteria for evaluating the effectiveness of segmentation approaches were used to evaluate the suitability of each approach for profiling the ESC consumer. Finally, this paper posits the S-P-P Model as an alternative approach for profiling the ESC consumer.

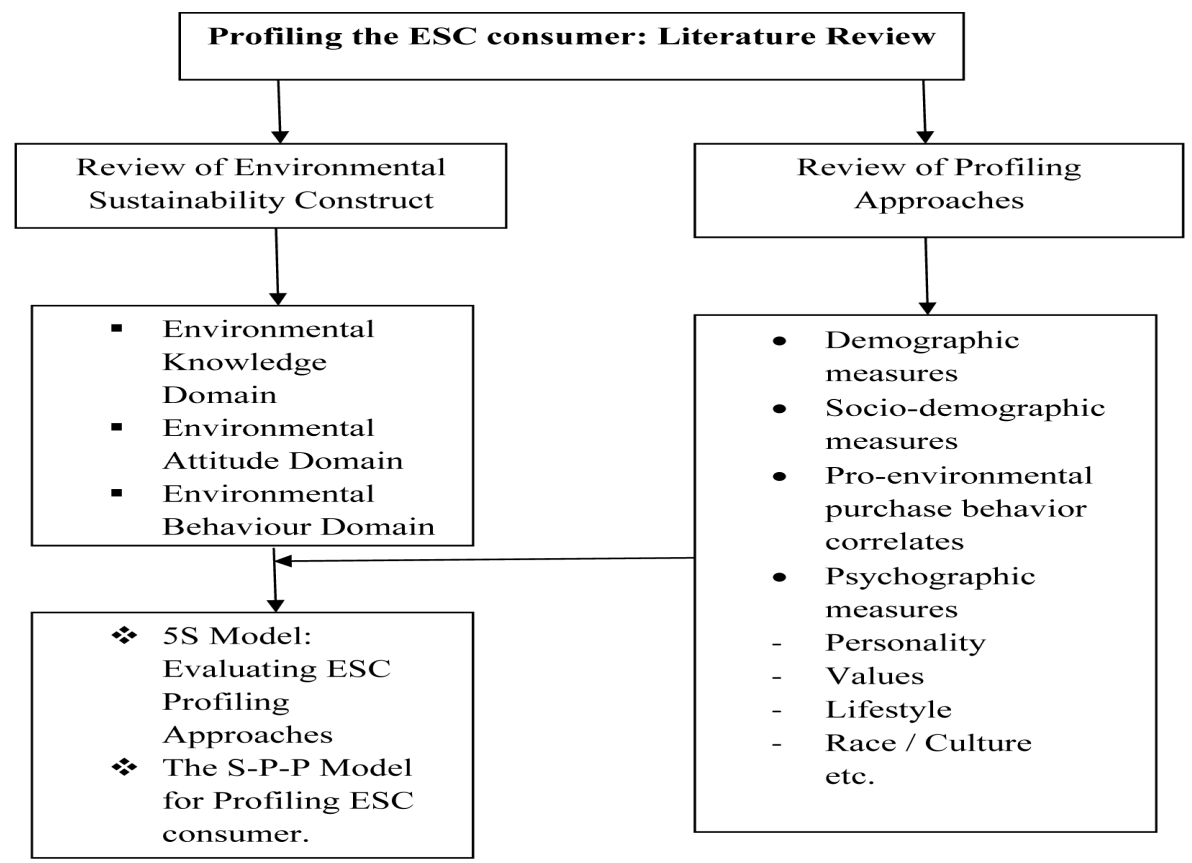

Figure 1. Literature review framework

Source: Authors' own conceptualization

\subsection{Environmental Sustainability Consciousness (ESC) Construct}

It has been reported that many scholars have studied and adopted the environmental consciousness construct in a wide range of social science fields, such as psychology, sociology, environmental studies, business research, and marketing (Diamantopoulos et al, 2003). Most of these studies, about $80 \%$, were conducted in the US, while only a few researches was conducted in Germany, Australia, France, Denmark, Israel, Canada, India, and Lithuania (Diamantopoulos et al, 2003). 
A wide range of environmental consciousness constructs have been employed in the past studies. The constructs include "environmental awareness" (Buttell et al., 1978), "environmental knowledge" (Balder-jahn, 1988), "environmental concern" (Kinnear et al. 1974; Tognacci et al. 1972; Zimmer et al. 1994), "perceived environmental effectiveness" (Ellen et al. 1991), and "environmental behaviour" which is expressed in "recycling behaviour" (Anderson et al. 1974; Vining et al., 1990), "conservation behaviour" (Geller, 1981; Leonard-Barton, 1981), "environmentally friendly purchase behaviour" (Davis, 1993; Ottman, 1992; Schwepker et al., 1991) and "ecologically conscious consumer behaviour (ECCB)" (Roberts, 1996). However, there is an existing problem in the past studies; that is, only one or select aspects of the environmental consciousness construct have been examined (Schlegelmich et al. 1996; Diamantopoulos et al., 2003). To deal with the problem, Diamantopoulos et al. (2003) recommended environmental consciousness construct be explained using the three domains: environmental knowledge, environmental attitude, and environmental behaviour. These three domains, which are commonly used as the dependent variables in the literature, were initially suggested by Bholen et al (1993).

\subsubsection{Environmental Knowledge Domain}

Environmental knowledge is also referred to ecoliteracy (Laroche et al, 2001). Knowledge is recognized in consumer research as a characteristic that influences all phases in the decision process. Specifically, knowledge is a relevant and significant construct that affects how consumers gather and organize information (Alba and Hutchinson, 1987), how much information is used in decision making (Brucks, 1985) and how consumers evaluate products and services (Murray and Schlacter, 1990).

Empirical support for the influence of consumers' environmental knowledge on their ecologically favourable behaviour is contradictory. On one hand, Maloney and Ward (1973) reported no significant linkage between environmental knowledge and ecologically compatible behaviour. On the other hand, Vining and Ebreo (1990), as well as Chan (1999), have shown that knowledge about ecological issues is a significant predictor of environmentally friendly behaviour. Amyx et al. (1994) found that individuals highly knowledgeable about environmental issues were more willing to pay a premium price for green products. Ecoliteracy was developed by Laroche et al. (1996) to measure the respondent's ability to identify or define a number of ecologically-related symbols, concepts and behaviours. It was found to be correlated with some attitudes and behaviour toward the environment.

The use of knowledge as a correlate of environmental consciousness should be with caution because knowledge influences all phases of the decision-making process, the wrong information can cause consumers to make a less perfect choice. For example, Bui (2005) citing Crane (2000) reported that most consumers assume that soapsuds clean their clothes better; when in actuality, soapsuds are only there to give the "impression" that your clothes will be cleaner - when in fact, soapsuds only harm the environment.

In addition, Bui (2005) maintained that it has been widely argued that consumers perceive most recycled materials as being inferior to non-recycled materials; the consumers generally assume the performance of most recycled products not to be at par with that of non-recycled products. And as Rao (1974) found, consumers are either uncertain or would not buy if non-polluting products were of poorer quality.

\subsubsection{Environmental Attitude Domain}

As regards the effects of environmental attitudes on behaviour, findings suggest that attitudes are the most consistent predictor of pro-environmental purchasing behaviours (Schlegelmilch, Greg, and Diamantopoulos 1996). What is key is whether attitudes predict actual behaviour. Generally, studies have found positive correlations between environmental concern (i.e., attitude) and environmental friendly behaviour (Van Liere and Dunlap 1981; Roberts and Bacon 1997). Simmons and Widmar (1990) found a significant relationship between environmental concern and ecologically responsible behaviour in the case of recycling. Berger and Corbin (1992) found that green consumers' behaviour could be influenced by their consumer perceived effectiveness (i.e., attitude) towards the protection of the environment. Others have found weak or insignificant relationships between attitudes and behaviour or substantial differences between intention and actual behaviour (Wicker 1969). Targeting a category of ecoconcerned consumers is thus much harder than marketers expected; findings are still relatively inconclusive in regards to the impacts of attitudes on behaviour.

According to Laroche et al (2001) "the two most studied attitudes in the ecological literature, with respect to environmentally friendly behavior, are importance and inconvenience." Amyx et al. (1994) define perceived importance, with respect to the environment, as the degree to which one expresses concern about ecological issues. In other words, importance is simply whether consumers view environmentally compatible behaviour as important to themselves or society as a whole. 
Inconvenience refers to how inconvenient it is perceived for the individual to behave in an ecologically favourable fashion. For example, a person may feel that recycling is important for the long-run good of the society, but he or she may also feel that it is personally inconvenient. McCarty and Shrum (1994) studied the impact of importance and inconvenience of recycling on the behaviour of recycling. They found that the relationship between inconvenience and recycling was in the expected direction, that is, the more individuals believed recycling was inconvenient, the less likely they were to recycle. By contrast, beliefs about the importance of recycling were not significantly related to recycling behaviour. Therefore, it appears that regardless of how important individuals believed recycling to be, the perception of the inconvenience of the recycling activity had a greater influence on their actions (Laroche et al, 2001).

\subsubsection{Environmental Behaviour Domain}

Suchard and Polonski (1991) stipulate that ecologically conscious consumers will try to protect the environment in different ways (e.g., recycling, checking that a package is made of recycled material, purchasing only green products). However, it is not clear how consumers' willingness to spend more for green product will be correlated with other ecologically favourable behaviours. Pickett et al. (1993) warned that marketers must exercise caution when attempting to extend environmental initiatives from one ecologically conscious behaviour to another. For example, those consumers who recycle paper may not be the same consumers who purchase recycled handwriting paper.

\section{Environmental Sustainability-Conscious (ESC) Consumer Profiling Approaches}

\subsection{The Use of Demographic Variables}

Demographics or demographic data are the characteristics of a human population as used in government, marketing or opinion research, or the demographic profiles used in such research. Commonly used demographics among these studies include gender, race, age, income, disabilities, mobility (in terms of travel time to work or number of vehicles available), educational attainment, home ownership, employment status, location, population density, and educational level of spouse.

Early studies on using demographic variables to identify environmentally friendly consumers was traced back to early 1970s by Laroche, Bergeron, and Barbaro-Forleo (2001) to the works of Berkowitz and Lutherman (1968) as well as Anderson and Cunningham (1972). According to Straughan and Roberts (1999) a number of past studies have made attempts to identify demographic variables that correlate with environmental sustainability conscious domains (e.g., Roberts, 1995; 1996b; Roberts and Bacon, 1997; Roper, 1990; 1992). Antil (1981) documented 16 studies that were carried out between 1971 to 1981; all studies used demographic variables for profiling the green segment. In their study, Diamatopoulos et. al (2003) reported 133 studies that were executed between 1966 to 1998 using only demographic variables to profile the environmental conscious consumers. Of their study, 88 were executed in the United States of America; 12 in the United Kingdom; 12 in Germany; 3 in Australia; 3 in Israel; 4 in Denmark; 2 in France; 3 in Canada; 4 in Sweden; and 2 in Netherlands. Since the study of Diamatopoulos and his associates, more country-specific studies have been carried out. For instance, a study has been executed in India (Jain and Kaur, 2006), in Lithuania (Banyte, Brazioniene, and Gadeikiene, 2010), all using demographic variables.

Although most findings about the impact of consumers' demographic characteristics on their environmentally conscious behaviour domains are contradictory (Roberts, 1990), it is clear that they exert a significant influence. Straughan and Roberts (1999) sustained that such variables, if significant, offer easy and efficient ways for marketers to segment the market and capitalize on green attitudes and behaviour. Accordingly, some authors have supported the use of demographic variables as the beginning point of any serious attempt to profile the sustainability conscious segment (for example, Roberts, 1990; Ottman \& Reilly, 1998; Straughan \& Roberts, 1999; Getzner \& Grabner-Kräuter, 2004). Supporting this perspective, Banyte et. al (2010, p.375) maintained that the "conception of green consumer is best reflected by his characteristics, it is purposeful to analyse the profile of a green consumer using the demographic approach." Although it is not enough to use demographic characteristics to determine the profile of green consumers, demographics undoubtedly provide certain set of common factors that gives useful information when segmenting consumers (D`Souza, Taghian, Lamb \& Peretaitko, 2007). There is little doubt that demographic variables present the easiest way to discriminate between those consumers who share a concern for the environment, and those who do not.

\subsection{The Use of Socio-Demographic Variables}

In addition to demographic variables mentioned above, some studies have profiled the environmental sustainability consumer using socio-demographic variables (e.g., Harry et al, 1969; Devall, 1970; Tognacci et al, 
1972; Ostman and Parker, 1987) wherein the social class element is combined with demographics. The argument in favour of the socio-demographic variables is that demographic variables alone cannot provide penetrating insight on the profile of this segment; hence the social class element is incorporated with other demographics.

In addition to the study of Diamantopolous et al (2003), there are twenty-two studies that have profiled environmental sustainability concern using the social class correlate. Five of these studies have investigated the impact of social class on environmental knowledge domain (Diamantopoulos et al, 2003). While Ostman and Parker (1987) and Meffert and Bruhn (1996) found no significant association, Arbuthnot and Lingg (1975) and Lyons and Breakwell (1994) reported positive relationships (Diamantopoulos et al, 2003).

Eleven of the twenty-two studies have explored the association between social class and environmental attitudes found significant positive relationships (Diamantopoulos et al, 2003). Moreover, the majority of observed patterns for studies failing to establish significant linkages have been in the positive direction (despite being non-significant). To explain the associations between social class and attitudes, it has been agreed that "( $t$ )hose persons most concerned about environmental issues appear to reflect the same configuration of social and psychological attributes which have traditionally characterized individuals active in civic, service, and political organisations"(Tognacci et al., 1972, p.85 in Diamantopoulos et al, 2003). It has also been proposed that concerns about environmental quality "may primarily embody 'status group' concerns"(Buttel and Flinn, [1978, p.436] in Diamantopoulos et al, 2003), "which are likely drawn from leisure interests associated with the environment. The assumption of the latter argument appears to be that the higher social classes are more likely to witness the effects of degradation of the natural environment through their outdoor leisure pursuits" (Diamantopoulos et al, 2003, p.471).

With respect to sustainability behaviour domain, most studies reported a positive association between social class and green behaviour (e.g., Lyons and Breakwell, 1994; Research, 2000 etc.). The explanation put forward by Diamantopoulos et al for this result is that higher social classes undertake higher levels of green behavior due to the very nature of the involvement required.

Diamantopoulos et al (2003) has questioned the efficacy of the socio-demographic approach on grounds that it offers limited utility for profiling environmentally conscious consumers in the UK, arguing that environmental concern is becoming the socially accepted norm within the Western culture. Thus they recommended an approach that combines socio-demographic variables and psychographic variable.

\subsection{The Use of Psychographic/Personality/Cultural Variables}

Psychographic variables are any attributes relating to personality, values, attitudes, interests, or lifestyles. They are also called IAO variables (for Interests, Activities, and Opinions). Psychographics can also be seen as an equivalent of the concept of "culture". Thus psychographics is the study of personality, values, attitudes, interests, and lifestyles.

Previous research has suggested that demographics alone have not proven to be adequate descriptors of ESC consumers (Anderson and Cunningham 1972; Brooker 1976; Kinnear, Taylor, and Ahmed 1974; Webster 1975; Diamantopoulos et al, 2003). Not only have the results of demographic analyses produced inconsistent results, but the relationships when found have been in general very weak (Antil, 1984). Accordingly, psychographic variables have been suggested in addition to demographic variables. Supporting this approach, Antil (1984, p.24) argued: "because few lifestyle data are currently available describing the socially responsible consumer, a psychographic analysis was viewed as a promising framework to provide a more in-depth and life-like view of this consumer segment."

A number of studies have attempted to identify psychographic correlates of green attitudes and behaviours (e.g. Antil, 1984; Hine and Gifford, 1991; Roberts, 1996; Stern et al, 1993; Straughan and Roberts, 1999; Banyte et al, 2010; etc.). Though these studies have not investigated psychographic variables in as exhaustive a manner as the research into demographics, they do provide some interesting insights into the nature of the green consumer (Straughan and Roberts, 1999). The main point put forward for the use of psychographic approach is that "peculiarities of consumer behaviour (attitude, knowledge, values) are closely related to their psychographic attributes (personal qualities, lifestyle, social class, etc.), which has an impact on their motives for buying an eco-friendly product and the like" (Banyte et al, 2010, p.377). Commonly examined psychographic correlates that are linked to the three environmental domains in the literature are: altruism, perceived consumer effectiveness, political orientation (conservatism and liberalism), individualism, collectivism, security and fun/enjoyment. Interestingly, conflict results are also recorded. The conflicting results are expected due to the different context, sample, and measure employed. 


\subsection{The Use of Pro-Environmental Purchase Behaviour Measure}

After highlighting the weakness of the socio-demographic and psychographic or personality approaches, Schlegelmilch, Bohlen, and Diamantopolous (1996) proposed the pro-environmental purchase behaviour segmentation approach, through an analysis of the linkages between proenvironmental purchase behaviour and measures of environmental consciousness. They argued that their approach rests on the rationale that consumers have traditionally been shown to express their environmental consciousness through the products they purchase. In the first wave of post-war enthusiasm for environmental protection during the late 1960s and early 1970s, being environmentally-concerned and being consumerist were seen as mutually exclusive. During this period, it was thought that the only way to cut down on pollution and solve the world's environmental problems, particularly natural resource depletion, was to cut down on consumption (Schlegelmilch et al, 1996). Throughout the 1970 s and 1980s, they argued that "green issues were not at the forefront of consumer concerns" (Schlegelmilch et al, 1996, p.47).

However, in recent years when the environment surged in importance, rather than cut down their consumption of products, they argued that consumers began to seek out environmentally-friendly alternatives in preference to their usual product purchases. Hence the "green" consumer was born. Their argument was supported with a number of studies. For example, in July 1989, a MORI (Market and Opinion Research International) poll revealed that the proportion of consumers selecting products on the basis of "environmental performance" had increased from 19 per cent to 42 per cent in less than a year (Elkington, 1989) and, by late 1992, a Nielsen study revealed that four out of five consumers were expressing their opinions about the environment through their purchasing behaviour." On the strength of these studies, they argued: "It is likely, therefore, that consumers who exhibit high levels of environmental consciousness make more green purchasing decisions than those exhibiting low levels" (Schlegelmilch et al, 1996, p.47). Hence they concluded that measures of environmental consciousness will be more closely related to purchasing habits than either socio-demographics or personality variables.

They developed eight variable items for pro-environmental purchasing behaviour and then linked them to three domains of environmental consciousness construct. Their study indicated that consumers' overall environmental consciousness has a positive impact on pro-environmental purchasing behaviour.

\section{Which Profiling Approach Is Most Suitable?}

It has long been held that the "ideal" approach to segmenting the market for any product is the approach that optimizes these five constructs - segment size; segment accessibility; simplicity/ease of identification; strategic/operational effectiveness; and segment stability (Straughan and Roberts, 1999). The current state of ecological consumer profiling will be examined in light of these criteria. Segment size: At this point in its development, few doubt that the overall market for green goods and services is large enough for, if properly managed, a firm to operate profitably (Roberts, 1995). As such, the size of green market segments is no longer in question, irrespective of the segmentation approach used. Segment accessibility: The accessibility of these segments, in terms of both logistics and communication, is not in doubt. For example, Straughan and Roberts (1999, p562) reported that "firms have clearly shown the ability to both communicate with ecologically conscious consumers and to reach them effectively with appropriate goods and services." As such, the usefulness of the various approaches to isolating ecologically conscious consumers from the mass market boils down to questions relating to ease of identification, usefulness in strategic and operational planning, and segment stability.

Simplicity or Ease of identification: as is often the case in marketing, the simplest segments to identify are based on demographic profiling. Perhaps that explains the relatively high volume of research done on demographic segmentation of ESC consumers. There is little doubt that demographic variables present the easiest way to discriminate between those consumers who share a concern for the environment, and those who do not. However, this ease cannot be said to be true for other approaches such as psychographic and pro-environmental purchase correlates. The real question that must be asked is this. How effective is demographic profiling for sustainability marketers?

Strategic/operational effectiveness: Whatever advantages demographic profiling of green consumers offers over psychographic profiling in terms of ease of use are more than offset by the relative strength of the associations between psychographic variables and ESC consumption. The strategic utility of socio-demographics has been questioned by a number of a number of authors (e.g., Schlegelmilch et al, 1996; Diamantopoulos, et al, 2003) that it lacks sufficient explanatory power of the ESC behaviour. The limited utility of socio-demographics may be explained by the fact that the environment is no longer a marginal issue; indeed, "environmental concern is 
becoming the socially accepted norm" (Schwepker and Cornwell, 1991:85). In other words, psychographic variables provide a stronger and therefore more useful profile of green consumption (Straughan and Roberts, 1999; Diamantopoulos et al, 2003) yet psychographic approach when used alone cannot provide better insight. For example, Roberts (1996b) cited in Straughan and Roberts (1999) reported an $\mathrm{R}^{2}$ of 0.06 for a model using age, sex, income, education, and occupation (all of which were individually statistically significant) to explain environmental conscious consumer behaviour (ECCB). In contrast, when psychographic correlates were introduced, $\mathrm{R}^{2}$ increased to 45 percent. Further strengthening this argument, altruism, a demonstrated psychographic correlate of green consumption, was not included in the Roberts (1996) study. In recent times, the operational and strategic utility of Psychographic and personality measures is being criticized in the sustainability literature. For instance, Hooley and Saunders (1993, p.145) suggest that caution should be taken in using personality variables for market segmentation according to behavioural criteria: "In most instances, personality measures are most likely to be of use for describing segments once they have been defined on some other basis.

Segment stability: Finally, when one considers the stability of resulting segments, there are serious questions raised regarding demographic profiling of green consumption. As discussed previously, the results of the demographic research range from equivocal to contradictory. Several explanations exist for these disparate findings. First, the various studies operationalize green consumption in a wide variety of ways. For example, the "dependent" variables used across these studies range from general attitude measures to incident analyses of specific types of environmentally friendly behaviour (e.g., household recycling). As such, study-to-study comparisons may be expected to result in seemingly contradictory findings. An alternative explanation for these contradictory findings, however, relates to the maturation of the sustainability marketing phenomena.

\section{Proposing the S-P-P Model for Profiling the ESC Consumer Segment}

The controversy regarding the appropriate approach that meets the $5 \mathrm{~S}$ Model criteria calls for a more sophisticated approach that integrates all the existing approaches and, at the same time, meets the $5 \mathrm{~S}$ criteria. Hence we posit the S-P-P Model as the most suitable model for profiling the ESC consumers.

The S-P-P Model is an integrated, holistic, mixed, and complex approach for profiling the ESC consumers. It integrates correlates of the socio-demographic approach, psychographic approach, and pro-environmental purchase approach. The proposed S-P-P Model is depicted in Figure 2.

With the S-P-P Model, a measuring scale that adequately reflects the various dimensions (e.g., psychographic measures) and sub-dimensions (e.g., values) of the model is necessary. Nonetheless, the subdimensions of the model are not watertight, in that a researcher may decide to contract the subdimensions under any dimension, subject to the peculiarities of the respondents and context where the research is being executed. In other words, to effectively profile the ESC consumer, the three dimension of the model is compulsory; that is, the width of the model is necessary but the depth could vary from context to context and from research to research.

As a way to enhance the validity and reliability of research outcomes, the S-P-P Model was conceptualized following the recommendation of researchers instead of using single behavioral measures of attitude, researchers should use multiple measures. For instance, Straughan and Roberts (1999) suggested that a mixed model incorporating a range of both demographics and psychographics should be preferred to the traditional demographic profiling methods in examining environmental concern as a correlate of environmental behaviour because psychographic variables provide stronger profiles of green consumption. Similarly, Roozen and De Pelsmacker (1998) recommended that conjoint analysis should be used to test attitudes and behaviour because this method can provide information on where consumers stand on the perceived "environmentally friendliness" of specific behaviour. It is on the strength of these recommendations that the present authors conceptualize the S-P-P Model.

Since research in the area of sustainability marketing is still relatively at the early stage and dominated by studies from developed nations of the world, it is important for scholars, especially those scholars who are executing studies from developing nations and the sub-Saharan Africa, to consider insight from the S-P-P model. No doubt, S-P-P approach to the research in the area of sustainability marketing will likely give a robust and reliable result.

\section{Conclusion and Implication}

\subsection{Findings}

In this review, a number of findings were made. First, this review showed that many authors have deconstructed the ESC consumer behaviour construct using three domains - knowledge, attitude, and behaviour. However, environmental ethics and attitude-behaviour domains are not commonly used in the literature to deconstruct the 
ESC construct. Secondly, contradictory perspectives exist in the literature regarding the approach that is most suitable for profiling the ESC consumer. Some scholars have opined that psychographic measures are most suitable over socio-demographic measures for profiling the ESC consumer (e.g., Diamantopoulos et al, 2003).

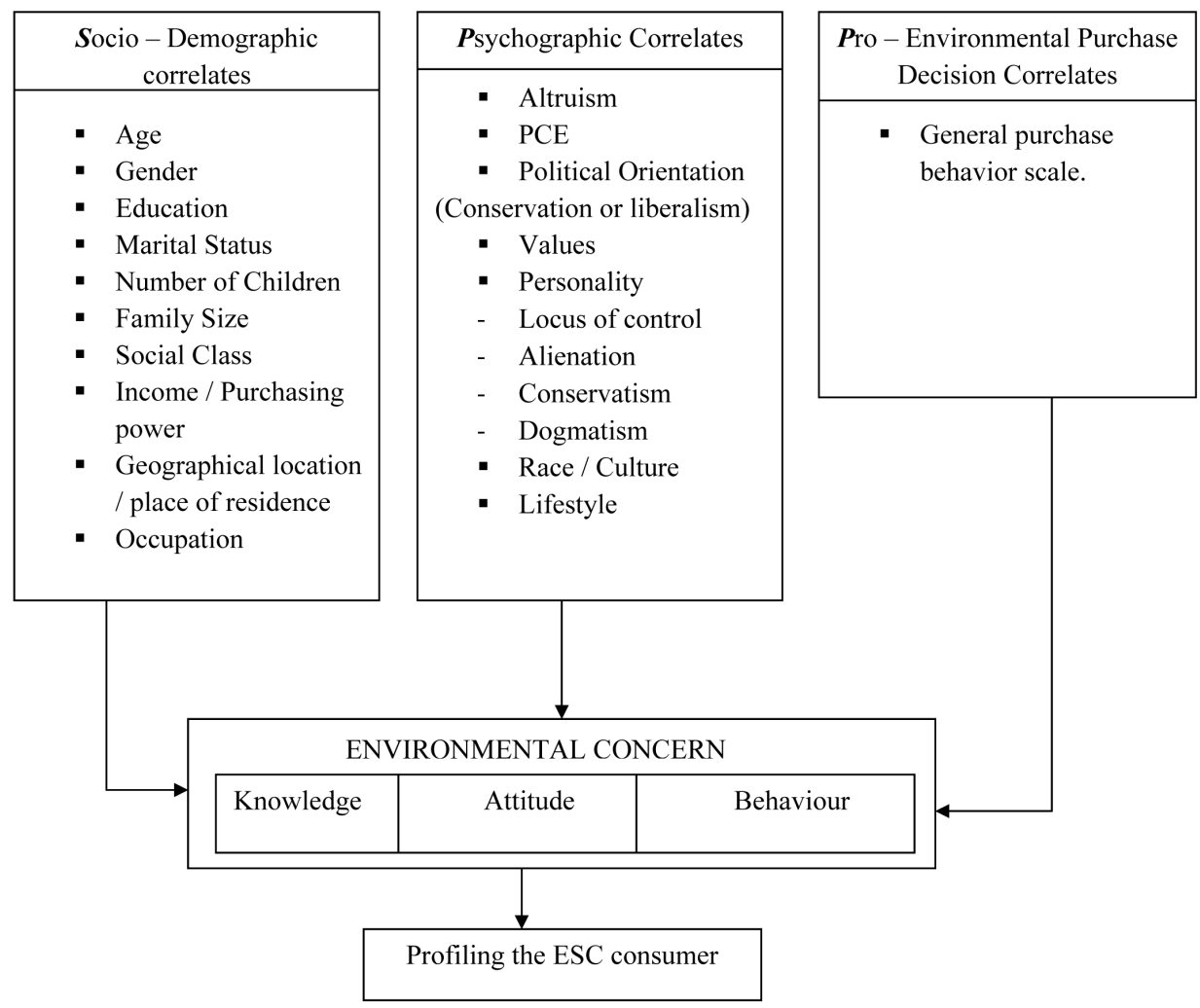

Figure 2. The S-P-P model for profiling ESC consumer

Source: Authors' own conceptualization

Some have argued in favour of demographic measures as being suitable as starting point and for providing initial insight into the ESC consumer (e.g., Laroche et al, 2001). Some authors have posited pro-environmental purchase decision approach, arguing that both socio-demographic measures and psychographic measures offer limited utility in profiling the ESC consumer (e.g., Schlegelmilch et al, 1996). To Schlegelmilch and associates, the purchase habit of the consumer provides better insights. Taken collectively, the contradictory perspectives have made inconclusive the argument as to which approach is most suitable for profiling the ESC consumer. Thirdly, akin to the second point above, the results on the common correlates (say, Age) used by scholars under each approach (say, socio-demographic) is contradictory. Few common results exist for each correlate. This is partly explained by the time, context, methodology adopted, as well as the evolving nature of the ESC consumer. Little wonder, country-specific study on profiling the ESC segment has been suggested (e.g., Hartono, 2008). Fourth, evidence from our evaluation of the various approaches for profiling the ESC consumer shows that none of the existing approaches survived the $5 \mathrm{~S}$ evaluation criteria. Accordingly, to mitigate this shortcoming, this review posits the S-P-P Model, which is an integrated and robust approach for profiling the ESC consumer segment.

The following propositions can guide research in the sub-Saharan African context. In the first example, we relate the "age" sub-dimension, which is a member of socio-demographic correlates, to the three broad domains of environmental concern.

\section{Example 1:}

Proposition 1: Younger people are more knowledgeable on environmental matters in sub-Sahara Africa. 
Proposition 2: Older people have positive attitude to the environment than the younger people in the sub-Saharan Africa region.

Proposition 3: Older people behave in a more environmentally responsible manner than the younger people in the sub-Saharan African region.

Similarly, the future researcher can develop proposition for other sub-dimensions of socio-demographic dimension (such as gender, education, marital status, number of children etc) and relate same to three domains.

\section{Example 2:}

Proposition 1: Altruistic individuals in the sub-Saharan Africa have knowledge of environmental issues.

Proposition 2: Altruistic individuals have better attitude to environmental issues than non-altruistic individuals.

Proposition 3: Altruistic people behave in an environmentally friendly manner than non-altruistic individuals.

The future researcher can develop proposition for other sub-dimensions of socio-demographic dimension (such as PCE (perceived consumer effectiveness), Political Orientation, values, personality, locus of control, etc.) and relate same to three domains of environmental concern.

\subsection{Recommendation}

Consequent upon the shortcomings of previous approaches for profiling the ESC consumer, this paper posits the S-P-P Model/approach. Studies to be executed on country-specific bases (especially the developing countries in Africa) should be executed using the S-P-P Model. Though not yet tested, it is envisaged that the S-P-P model will provide robust, detailed, constructive, and penetrating insight about the ESC consumer. This paper provides a very useful insight about the ESC segment generally, thus providing ESC companies with background information on how best to target the ESC consumer segment; while encouraging context/country-specific study that employs the S-P-P model to unearth the profile of this consumer segment.

\subsection{Limitations}

This review is marred by a number of shortcomings. First, this review is not exhaustive, in that it did not review methodological issues (such as sampling, measurement instrument, and scale development) that underpin each of profiling approaches. Second, this review only mention about the qualitative effects of demographic variables, socio-demographic variables, and psychographic/personality/ cultural variables on environmental sustainability consumer in the previous studies, but did not show their quantitative effects which is especially crucial for readers to perceive the role of each explanatory variables had played in ESC and evaluate the probable effects of each variables used in the S-P-P model on ESC. Third, S-P-P model was constructed from literature review to analyze the impacts of demographic, socio-demographic, and psychographic/personality/ cultural variables on ESC, and have listed the variables probably influencing ESC (in Figure 2), there is lack of empirical evidence to foster readers understand the importance of each variable, especially whether the variables probably influencing ESC in the sub-Saharan Africa are different from those obtained in the developed countries. This shortcoming underscores the need for the S-P-P model to be empirically tested in the sub-Saharan African context. Four, the review failed to describe the statically or econometric methods for researchers and readers to estimate the S-P-P model. The foregoing shortcomings provide opportunities for further research and review.

\section{References}

Aaker, D. A., \& Bagozzi, R. P. (1982). Attitudes toward public policy alternatives to reduce air pollution. Journal of Marketing, 1(1), 85-94.

Ajzen, I., \& Fishbein, M. (1977). Attitude-behaviour relations: A theoretical evaluation review of empirical research. Psychological Bulletin, 84, 888 - 918. http://dx.doi.org/10.1037/0033-2909.84.5.888

Anderson, T. Jr., \& Cunningham, W. H. (1972). The socially conscious consumer. Journal of Marketing, 36(7), 23-31. http://dx.doi.org/10.2307/1251036

Anderson, W. T. Jr., Henion, K. E., \& Cox, E. P. III. (1974). Socially vs ecologically responsible consumers. AMA Combined Conference Proceedings, 36, Spring and Fall, 304-311.

Antil, J. H. (1984). Socially responsible consumers: Profile and implications for public policy. Journal of Macromarketing, 5(18), 18-39.

Arbuthnot, J. (1977). The roles of attitudinal and personality variables in the prediction of environmental behavior and knowledge. Environment and Behavior, 9(6), 217-232. http://dx.doi.org/10.1177/001391657792004 
Arbuthnot, J., \& Lingg, S. (1975). A comparison of French and American environmental behaviours, knowledge and attitude. International Journal of Psychology, 10(4), 275-281. http://dx.doi.org/10.1080/00207597508247339

Arcury, T. A., Scollay, S. J., \& Johnson, T. P. (1987). Sex differences in environmental concern and knowledge: the case of acid rain. Sex Roles, 16(9/10), 463-472. http://dx.doi.org/10.1007/BF00292481

Banyte, J., Brazioniene, L., \& Gadeikiene, A. (2010). Investigation of Green Consumer Profile: A case of Lithuanian market of eco-friendly food products. Economics and Management, 1(15), 374-383.

Belz, F., \& Peatie, K. (2010). Sustainability Marketing. London: John Wiley \& Sons Ltd.

Berger, I. E., \& Corbin, R. M. (1992). Perceived consumer effectiveness and faith in others as moderators of environmentally responsible behaviour. Journal of Public Policy \& Marketing, 11(2), 79 - 88.

Berkowitz, L., \& Lutterman, K. G. (1968). The traditional socially responsible personality. Public Opinion Quarterly, 32, 169-85. http://dx.doi.org/10.1086/267597

Bohlen, G. M., Schlegelmilch, B. B., \& Diamantopoulos, A. (1993). Measuring ecological concern: a multi-construct perspective. Journal of Marketing Management, 9(4), 415-430. http://dx.doi.org/10.1080/0267257X.1993.9964250

Brooker, G. (1976). The self-actualizing socially conscious consumer. Journal of Consumer Research, 3(4), 107-112. http://dx.doi.org/10.1086/208658

Brucks, M. (1985). The effects of product knowledge on information search behaviour. Journal of Consumer Research, 12(6), 1-16. http://dx.doi.org/10.1086/209031

Bui, M. H. (2005). Environmental Marketing: A model of consumer behaviour. Proceedings of the annual meeting of the Association of Collegiate Marketing Educators. New Olrleans.

Burnett, J., \& Dunne, P. M. (1986). An appraisal of the use of student subjects in marketing research. Journal of Business Research, 14(August), 329-443. http://dx.doi.org/10.1016/0148-2963(86)90024-X

Buttell, F. H., \& Flinn, W. L. (1978). The politics of environmental concern: Impacts of party identification and political ideology on environmental attitudes. Environment and Behaviour, 10(1), 17-37. http://dx.doi.org/10.1177/0013916578101002

Chan, K. (1999). Market segmentation of green consumers in Hong Kong. Journal of International Consumer Marketing, 12(2), 7-24. http://dx.doi.org/10.1300/J046v12n02_02

Chan, T. S. (1996). Concerns for environmental issues and consumer purchase preferences: A two-country study. Journal of International Consumer Marketing, 9(1), 43-55. http://dx.doi.org/10.1300/J046v09n01_04

Chandler, R. (1972). Public opinion: changing attitudes on contemporary political and social issues. New York: RR Bowker.

Coddington, W. (1990). It's no fad: environmentalism is now a fact of corporate life. Marketing News, 15, October, 7.

Crane, Andrew. (2000). Facing the backlash: green marketing and strategic reorientation in the 1990's. Journal of Strategic Marketing, 8(4), 277 - 296. http://dx.doi.org/10.1080/09652540050110011

D'Souza, C., Taghian, M., \& Lamb, P. (2006). An empirical study on the influence of environmental labels on consumers. Corporate Communications: An International Journal, 11(2), 162-173. http://dx.doi.org/10.1108/13563280610661697

D’Souza, C., Taghian, M., Lamb, P., \& Pretiatko, R. (2007). Green decisions: demographics and consumer understanding of environmental labels. International Journal of Consumer Studies, 31, 371-376. http://dx.doi.org/10.1111/j.1470-6431.2006.00567.x

Davidson, D. J., \& Freudenburg, W. R. (1996). Gender and environmental risk concerns: a review and analysis of available research. Environ Behav, 28(3), 302-339. http://dx.doi.org/10.1177/0013916596283003

Davis, J. J. (1993). Strategies for environmental advertising. Journal of Consumer Marketing, 10(2), 19-36. http://dx.doi.org/10.1108/07363769310039102

Devall, W. B. (1970). Conservation: An upper-middle class social movement, a replication. Journal of Leisure Research, 3, 123-6. 
Diamantopoulos, A., Schlegelmilch, B. B., \& Sinkovics, R. R. (2003). Can socio-demographics still play a role in profiling green consumers? A review of the evidence and an empirical investigation. Journal of Business Research, 56(2003), 465-480. http://dx.doi.org/10.1016/S0148-2963(01)00241-7

Do Paço, A. M. F., Raposo, M. L. B., \& Filho, W. L. (2009). Identifying the green consumer: a segmentation study. Journal of Targeting, Measurement and Analysis for Marketing, 17(1), 17-25. http://dx.doi.org/10.1057/jt.2008.28

Eagly, A. H. (1987). Sex Differences in Social Behaviour: A Social-role Interpretation. New Jersey: Lawrence Erlbaum Associates.

Elkington, J. (1989). Why it pays to be green. Weekend Financial Times, October 14, 13.

Ellen, P. S., Weiner J. L., \& Cobb-Walgren, C. (1991). The role of Perceived Consumer Effectiveness in Motivating Environmentally Conscious Behaviours. Journal of Public Policy and Marketing, 10(fall), 102-117.

Getzner, M., \& Grabner-Kräuter, S. (2004). Consumer preferences and marketing strategies for "green shares". Specifics of the Austrian market. International Journal of Bank Marketing, 4, $260-278$. http://dx.doi.org/10.1108/02652320410542545

Grunert, S. C. (1991). Everybody seems concerned about the environment: but is this concern reflected in (Danish) consumers' food choice? Paper prepared for a special session at The ACR Summer Conference, Amsterdam, June.

Harry, J., Gale, R., \& Hendee, J. (1969). Conservation: An upper-middle class social movement. Journal of Leisure Research, 2, 246-54.

Hartono, A. (2008). Adopting socio-demographic characteristics in profiling green consumers: A review of hypotheses. Jurnal Siasat Bisnis, 12(1).

Henion, K. E. (1976). Ecological Marketing. Columbus: Grid.

Hine, D. W., \& Gifford, R. (1991). Fear appeals, individual differences, and environmental concern. The Journal of Environmental Education, 23(1), 36-41. http://dx.doi.org/10.1080/00958964.1991.9943068

Honnold, J. A. (1981). Predictors of public environmental concern in the 1970s. In Mann DE (Ed.), Environmental policy formation - the impacts of values, ideology and standards (pp. 63- 75). Lexington: Lexington Books.

Hooley, G. J., \& Saunders, J. (1993). Competitive Positioning: The Key to Marketing Strategy. Prentice-Hall International, London.

Hounshell, P., \& Liggett, L. (1973). Assessing the effectiveness of environmental education. Journal of Environmental Education, 5(2), 28-30.

Hume, S., Strand, P., Fisher, C., Fitzgerald, K., \& Freeman, L. (1989). Consumers gogreen. Advertising Age, $4(25), 3-5$.

Jackson, E. L. (1985). Environmental attitudes and preferences for energy resource options. Journal of Environmental Education, 17, 23-30. http://dx.doi.org/10.1080/00958964.1985.9941395

Jain, S. K., \& Kaur, G. (2006). Role of Socio-demographics in Segmenting and Profiling Green Consumers: An Exploratory Study of Consumers in India. Journal of International Consumer Marketing, 18(3), $107-142$. http://dx.doi.org/10.1300/J046v18n03_06

Jolibert, A., \& Baumgartner, G. (1981). Toward a definition of the consumerist segment in France. Journal of Consumer Research, 8(June), 114-117. http://dx.doi.org/10.1086/208847

Kassarjian, H. H. (1971). Incorporating ecology into marketing strategy: The case of air pollution. Journal of Marketing, 35(3), 61-5. http://dx.doi.org/10.2307/1249791

Kinnear, T. C., Taylor, J. R., \& Ahmed, S. A. (1974). Ecologically concerned consumers: who are they? Journal of Marketing, 38(3), 20-24. http://dx.doi.org/10.2307/1250192

Laroche, M., Toffoli, R., Kim, C., \& Muller, T. E. (1996). The influence of culture onpro-environmental knowledge, attitudes, and behaviors: a Canadian perspective. In Corfman, K. P., \& Lynch, J. G. (Eds.), Advances in Consumer Research (pp. 196-202). Association for Consumer Research, Provo, UT. 
Laroche, M. L., Bergeron, J., \& Barbaro-Forleo, G. (2001). Targeting Consumers who are willing to pay more for environmentally friendly products. Journal of Consumer Marketing, 18(6), 503-520. http://dx.doi.org/10.1108/EUM0000000006155

Leonard-Barton, D. (1981). Voluntarily simplicity lifestyles and energy consumption. Journal of Consumer Behaviour, 8(6), 243-252.

Lyons, E., \& Breakwell, G. M. (1994). Factors predicting environmental concern and indifference in 13- to 16-year-olds. Environ Behav, 26(2), 223 -238. http://dx.doi.org/10.1177/001391659402600205

MacDonald, W. L., \& Hara, N. (1994). Gender differences in environmental concern among college students. Sex Roles, 33(5/6), 369-674. http://dx.doi.org/10.1007/BF01544595

Maloney, M. P., \& Ward, M. P. (1973). Ecology: let's hear from the people: an objective scale for the measurement of ecological attitudes and knowledge. American Psychologist, 7, 583-586. http://dx.doi.org/10.1037/h0034936

Maloney, M. P., Ward, M. P., \& Braught, G. N. (1975). A revised scale for the measurement of ecological attitudes and knowledge. American Psychologist, 30(July), 787-790. http://dx.doi.org/10.1037/h0084394

McCarty, J. A., \& Shrum, L. J. (1994). The recycling of solid wastes: personal values, value orientations, and attitudes about recycling as antecedents of recycling behaviour. Journal of Business Research, 30(1), 53-62. http://dx.doi.org/10.1016/0148-2963(94)90068-X

McEvoy, J. III. (1972). The American concern with the environment Social Behavior. Natural Resources and the Environment.

Meffert, H., \& Bruhn, M. (1996). Das Umweltbewußtsein von Konsumenten. Die Betriebswirtsch, 56(5), 62148.

Moore, H. K. (1981). Energy related information-Attitude measures of col-lege-age students. Journal of Envi-ronmental Education, 12(1), 30-3. http://dx.doi.org/10.1080/00958964.1981.9942639

Murphy, P. E., Kangun, N., \& Locander, W. B. (1978). Environmentally concerned consumers racial variations. Journal of Marketing, 54(October), 61-66. http://dx.doi.org/10.2307/1250087

Murray, K. B., \& Schlacter, J. L. (1990). The impact of services versus goods on consumer's assessment of perceived risk and variability. Journal of the Academy of Marketing Science, 18(1), 51-65. http://dx.doi.org/10.1007/BF02729762

Myburgh-Louw, J., \& O'Shaughnessy, N. J. (1994). Consumer perception of misleading and deceptive claims on the packaging of 'green' fast moving consumer goods. In Achrol, R., \& Mitchell, A. (Eds.), AMA Summer Educators' Conference Proceedings (pp. 344-353). American Marketing Association, Chicago, IL.

Neuman, K. (1986). Personal values and commitment to energy conservation. Environmental Behaviour, 18(1), 53 -74. http://dx.doi.org/10.1177/0013916586181003

Ostman, R. E., \& Parker, J. I. (1987). Impact of education, age, newspapers, and television on environmental knowl-edge, concerns, and behaviours. Journal of Environmental Education, 19(1), 3-9.

Ottman, J. A., \& Reilly, W. R. (1998). Green marketing: Opportunity for innovation. London: Prentice Hall Inc.

Ottman, J. A. (1992). Green Marketing: Challenges and Opportunities for the New Marketing Age. Lincolnwood, IL: NTC Business Books.

Peattie, K. (1999). Trappings versus substance in the greening of marketing planning. Journal of Strategic Marketing, 7(4), 131-148. http://dx.doi.org/10.1080/096525499346486

Pickett, G. M., Grove, S. J., \& Kangun, N. (1993). An analysis of the conserving consumer: a public policy perspective. In Allen, C.T. et al. (Eds.), AMA Winter Educators' Conference Proceedings (Vol. 3, pp. 151-3). American Marketing Association, Chicago, IL.

Rao, C. P. (1974). Consumer ecological concern and adaptive behaviour. Journal of the Academy of Marketing Science, 2(1), 262-278. http://dx.doi.org/10.1007/BF02729519

Ray, J. J. (1975). Measuring environmentalist attitudes. Aust $N$ Z J Sociol, 11(2), 70-71. http://dx.doi.org/10.1177/144078337501100218

Research. (2000). Consumers and the environment: the impact of environmental change on attitudes and purchasing behaviour. Environ Attitudes Surv 1 (Sept. 1990). 
Roberts, J. A. (1990). Green consumers in the 1990s: profile and implications for advertising. Journal of Business Research, 36, 226-245.

Roberts, J. A. (1995). Profiling levels of socially responsible consumer behavior: a cluster analytic approach and its implications for marketing. Journal of Marketing Theory and Practice, fall, 97-117.

Roberts, J. A. (1996a). Will the real socially responsible consumer please step forward? Business Horizons, January-February, 79-83. http://dx.doi.org/10.1016/S0007-6813(96)90087-7

Roberts, J. A. (1996b). Green consumers in the 1990s: profile and implications for advertising. Journal of Business Research, 36(3), 217-231. http://dx.doi.org/10.1016/0148-2963(95)00150-6

Roberts, J. A., \& Bacon, D. R. (1997). Exploring the subtle relationships between environmental concern and ecologically conscious consumer behaviour. Journal of Business Research, 40(1), 79-89. http://dx.doi.org/10.1016/S0148-2963(96)00280-9

Roozen, I., \& De Pelsmacker, P. (1998). Attributes of Environmentally Friendly Consumer Behaviour. Journal of International Consumer Marketing, 10(3), 21. http://dx.doi.org/10.1300/J046v10n03_03

Roper Organization. (1990). The Environment: Public Attitudes and Individual Behaviour. Commissioned by S.C. Johnson and Son, Inc.

Roper Organization. (1992). Environmental Behavior, North America: Canada, Mexico, United States. Commissioned by S.C. Johnson and Son, Inc.

Samdahl, D. M., \& Robertson, R. (1989). Social determinants of environmental concern: specification and test of the model. Environment and Behaviour, 21(1), 57-81. http://dx.doi.org/10.1177/0013916589211004

Schahn, J., \& Holzer, E. (1990). Studies of individual environmental concern: the role of knowledge, gender, and background variables. Environ Behav, 22(6), 767- 86. http://dx.doi.org/10.1177/0013916590226003

Schlegelmilch, B. B., Bohlen, G. M., \& Diamantopoulos, A. (1996). The link between green purchasing decisions and measures of environmental consciousness. European Journal of Marketing, 30(5), 35-55. http://dx.doi.org/10.1108/03090569610118740

Schwepkar, C. H. Jr., \& Cornwell, T. B. (1991). An examination of ecologically concerned consumers and their intentions to purchase ecologically-packaged products. Journal of Public Policy and Marketing, 10(2), 77-101.

Scott, D., \& Willits, F. K. (1994). Environmental attitudes and behavior: a Pennsylvania survey. Environment and Behaviour, 26(2), March, 239-260. http://dx.doi.org/10.1177/001391659402600206

Simmons, D., \& Widmar, R. (1990). Motivations and barriers to recycling: Toward a strategy for public education. The Journal of Environmental Education, $22,13-18$. http://dx.doi.org/10.1080/00958964.1990.9943041

Stern, P. C., Dietz, T., \& Kalof, L. (1993). Value orientations, gender, and environmental concern. Environment and Behavior, 25(3), 322-48. http://dx.doi.org/10.1177/0013916593255002

Straughan, R. D., \& Roberts, J. A. (1999). Environmental segmentation alternatives: a look at green consumer behaviour in the new millennium. Journal of Consumer Marketing, 16(6), 558-575.

Suchard, H. T., \& Polonski, M. J. (1991). A theory of environmental buyer behaviour and its validity: the environmental action-behaviour model. In Gilly, M.C. et al. (Eds.), AMA Summer Educators' Conference Proceedings (Vol. 2, pp. 187-201). American Marketing Association, Chicago, IL.

Tognacci, L. N., Weigal, R. H., Wideen, M. F., \& Vernon, D. T. (1972). Environmental quality: how universal is public concern? Environment and Behaviour, 4(3), 73-86. http://dx.doi.org/10.1177/001391657200400103

Ukenna, S. I. (2010). Consumer Sales Promotion Effectiveness: An Examination of Consumer Sales Promotion Technique Preferences of Nigerian Consumers. Unpublished PhD Seminar Paper, Nnamdi Azikiwe University, Awka, Nigeria.

Van Liere, K., \& Dunlap, R. (1981). The social bases of environmental concern: a review of hypotheses, explanations, and empirical evidence. Public Opinion Quarterly, 44(2), 181-197. http://dx.doi.org/10.1086/268583

Vining, J., \& Ebreo, A. (1990). What makes a recycler? A comparison of recyclers and non-recyclers. Environ Behav, 22(1), 55 -73. http://dx.doi.org/10.1177/0013916590221003 
Webster, F. E. Jr. (1975). Determining the characteristics of the socially conscious consumer. Journal of Consumer Research, 2(12), 188-196. http://dx.doi.org/10.1086/208631

Weigel, R. H. (1983). Environmental psychology: Directions and perspectives. New York: Praeger.

Wicker, A. W. (1969). Attitudes versus action: The relationship of verbal and overt behavioural responses to attitude objects. Journal of Social Issue, 25(4), 41 -78. http://dx.doi.org/10.1111/j.1540-4560.1969.tb00619.x

Wiener, J. L, \& Doescher, T. A. (1991). A framework for promoting cooperation. J Mark, $55(2), 38$ - 47. http://dx.doi.org/10.2307/1252236

Wind, D. E. (2004). Green consumer psychology and buying strategies. Prentice Hall.

World Wildlife Fund. (2006). Living Planet Report. New York: WWF Publishers.

Zeidner, M., \& Shechter, M. (1988). Psychological responses to air pollution. Somevpersonality and demographic correlates. J Environ Psychol, 8, 191- 208. http://dx.doi.org/10.1016/S0272-4944(88)80009-4

Zimmer, M. R., Stafford, T. F., \& Stafford, M. R. (1994). Green issues: dimensions of environmental concern. Journal of Business Research, 30(1), 63-74. http://dx.doi.org/10.1016/0148-2963(94)90069-8 